\title{
Faktor Risiko Air Ketuban Keruh Terhadap Kejadian Sepsis Awitan Dini pada Bayi Baru Lahir
}

\author{
Muhammad Sholeh Kosim, * Arsita Eka Rini, * Lisyani B Suromo** \\ *Bagian Ilmu Kesehatan Anak FK Universitas Diponegoro/RSUP Dr. Kariadi Semarang \\ ** Bagian Patologi Klinik FK Universitas Diponegoro/RSUP Dr.Kariadi Semarang
}

\begin{abstract}
Latar belakang. Sepsis neonatorum merupakan masalah utama dan penyebab kematian terbanyak di negara berkembang. Air ketuban keruh bercampur mekonium merupakan salah satu faktor risiko sepsis bayi baru lahir dan terjadi pada sekitar 10\%-20\% seluruh kelahiran.

Tujuan. Membuktikan air ketuban keruh merupakan faktor risiko kejadian sepsis awitan dini pada bayi baru lahir.

Metode. Penelitian menggunakan desain kohort. Subjek adalah bayi dengan kriteria inklusi dan lahir dengan air ketuban keruh bercampur mekonium di RS Dr. Kariadi bulan Oktober 2009 - Maret 2010. Bayi lahir dengan air ketuban jernih sebagai kontrol. Air ketuban diambil pada hari ke-1, biakan darah, dan pemeriksaan darah tepi pada hari ke-5. Analisis statistik menggunakan chi square, Mann Whitney, dan risiko relatif ( $95 \%$ confidence interval).

Hasil. Subjek 70 bayi lahir dengan air ketuban keruh berisiko 10x lebih tinggi mengalami sepsis (95\% $\mathrm{CI}=1,3-74,0 ; \mathrm{p}=0,003)$. Risiko relatif adanya kuman pengecatan Gram (+) di dalam air ketuban terhadap terjadinya sepsis $1,4(95 \% \mathrm{CI}=0,3-6,8 ; \mathrm{p}=0,6)$ dan adanya kedua jenis kuman Gram (+) dan (-) 2,4 (95\% $\mathrm{CI}=0,7-7,7 ; \mathrm{p}=0,2)$. Risiko relatif bayi dengan air ketuban mengandung biakan $E$ coli mempunyai risiko kejadian sepsis 3,8 $(95 \% \mathrm{CI}=0,8-17,0 ; \mathrm{p}=0,057)$ dan biakan non $E$ coli $2,4(95 \% \mathrm{CI}=0,4-13,1 ; \mathrm{p}=0,4)$. Faktor risiko lain adalah adanya kuman dalam biakan darah, berisiko 6,3 x lebih tinggi mengalami sepsis (95\% CI=1,4-29,3; p=0,02).

Kesimpulan. Air ketuban keruh merupakan faktor risiko terjadinya sepsis bayi baru lahir awitan dini. Jenis kuman pengecatan Gram dan biakan kuman dalam air ketuban bukan merupakan faktor risiko terjadinya sepsis awitan dini. Sari Pediatri 2010;12(3):135-41.
\end{abstract}

Kata kunci: sepsis, air ketuban keruh bercampur mekonium

\footnotetext{
Alamat korespondensi:

Dr. M. Sholeh Kosim, Sp.A(K). Sub Bagian Perinatologi Bagian IKA FK UNDIP/RSUP Dr.Kariadi Semarang E-mail : mskosim@indosat.net.id Dr. Arsita Ekarini: E-mail: arsitaekarini@yahoo.com
}

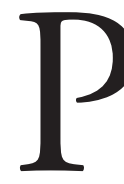

enyakit infeksi dan sepsis neonatorum merupakan masalah utama yang belum dapat terpecahkan sampai saat ini. Di negara berkembang, hampir sebagian besar bayi baru lahir (BBL) 
yang dirawat mempunyai kaitan dengan masalah infeksi. Hal yang sama ditemukan di negara maju pada bayi yang dirawat di unit perawatan intensif neonatus. ${ }^{1}$ Penyebab kematian BBL di negara berkembang berturut-turut adalah penyakit infeksi (42\%), asfiksia dan trauma lahir (29\%), bayi kurang bulan dan berat lahir rendah (10\%), kelainan bawaan (14\%) dan sebab lain (4\%). ${ }^{2}$ Angka kematian bayi (infant mortality rate / IMR), 2/3 dari seluruh kematian bayi di bawah satu tahun merupakan kematian bayi usia kurang satu bulan (neonatal mortality rate), dua pertiga di antaranya merupakan kematian bayi usia kurang satu minggu (early neonatal mortality rate) dan dua pertiga dari jumlah tersebut meninggal dalam usia 24 jam pertama. Disimpulkan bahwa kematian neonatus merupakan komponen utama kematian bayi yaitu angka yang dipakai sebagai indikator kemajuan kesehatan di suatu negara (Data Sistim Kesehatan Nasional). ${ }^{3}$ Laporan WHO yang dikutip Child Health Research Project Special Report. reducing perinatal and neonatal mortality tahun 1999 mengemukakan bahwa 42\% kematian BBL terjadi karena berbagai bentuk infeksi. ${ }^{2}$

Angka kejadian sepsis di negara berkembang masih cukup tinggi (1,8-18/1000) dibandingkan negara maju $(1-5 / 1000){ }^{4}$ Di RS Cipto Mangunkusumo Jakarta tahun 2005 kejadian sepsis 13,68\% kelahiran hidup dengan kematian $14,18 \%{ }^{5}$ sedang di RS Dr. Kariadi Semarang tahun 2004 kejadian 33,1\% dengan kematian $20,3 \%{ }^{6}$

Faktor risiko terjadinya sepsis neonatal yang didapat dari ibu meliputi ketuban pecah dini/lebih 18 jam, demam lebih $38^{\circ} \mathrm{C}$, cairan ketuban hijau, keruh dan berbau, serta kehamilan multipel. Faktor risiko pada bayi meliputi prematuritas, berat lahir rendah, gawat janin, asfiksia neonatorum, serta faktor lain yaitu prosedur cuci tangan yang tidak benar. ${ }^{5}$

Beberapa kepustakaan menyebutkan bahwa air ketuban keruh (air ketuban bercampur mekonium) merupakan salah satu faktor risiko ibu yang menyebabkan terjadinya sepsis bayi baru lahir. ${ }^{7,8}$ Air ketuban keruh terjadi kurang lebih 10\%-20\% dari seluruh kelahiran. Beberapa studi memperlihatkan adanya hubungan antara air ketuban keruh dengan infeksi maternal. ${ }^{9}$ Air ketuban keruh yang menimbulkan komplikasi terjadi sekitar 9\%-20\% dari kehamilan dan terjadi lebih dari 500.000 kasus per tahun di Amerika Serikat. ${ }^{10}$ Jazayeri ${ }^{9}$ dalam penelitiannya melaporkan endometritis meningkatkan risiko terjadinya air ketuban keruh, namun tidak demikian dengan korioamnionitis. Tran $\mathrm{dkk}^{11}$ melaporkan adanya air ketuban bercampur mekonium berhubungan dengan terjadinya infeksi nifas. Semakin keruh air ketuban risiko infeksi semakin meningkat. Rao dkk ${ }^{12}$ menyimpulkan adanya mekonium dalam air ketuban berpotensi menyebabkan infeksi dan meningkatkan morbiditas neonatal. Laporan terkini telah mengidentifikasi air ketuban bercampur mekonium sebagai salah satu faktor risiko untuk terjadinya infeksi intra amnion dan endometritis post partum. Secara in vitro air ketuban yang diberi mekonium dengan konsentrasi $1 \%$ menyokong terjadinya pertumbuhan bakteri. ${ }^{10} \mathrm{Pada}$ infeksi intraamnion, koloni kuman yang ditemukan adalah bakteria anaerobik, group B Streptococcus (GBS), Eschericia coli dan mikoplasma daerah genital. ${ }^{13}$

Air ketuban keruh sering merupakan penyebab terjadinya sindrom aspirasi mekonium yang selanjutnya dapat berkembang menjadi asfiksia neonatorum dan merupakan salah satu faktor risiko terjadinya sepsis. Namun akhir-akhir ini didapatkan kenyataan bahwa tidak semua bayi yang lahir dengan air ketuban keruh kemudian berkembang menjadi sepsis. Bayi yang lahir bugarpun dapat berkembang menjadi sepsis.

\section{Metode}

Desain penelitian kohort, subjek bayi baru lahir dengan air ketuban keruh di RSUP Dr. Kariadi Semarang, periode Oktober 2009-Maret 2010. Kriteria inklusi yaitu lahir dan dirawat di bangsal rawat gabung (RG), perawatan bangsal risiko tinggi (PBRT), neonatal intensive care unit (NICU) RS Dr. Kariadi, lahir cukup bulan atau lebih bulan, berat lahir $\geq 2500$ gram, lahir letak kepala secara spontan atau partus tindakan seperti vakum ekstraksi dan sectio cesaria. Bayi tidak diikutsertakan apabila menderita kelainan kongenital berat, orang tua / wali tidak mengijinkan, ibu bayi menunjukkan tanda infeksi sistemik secara klinis sebelum melahirkan yaitu demam pada saat melahirkan (suhu tubuh $\geq 37,8^{\circ} \mathrm{C}$ ), takikardi (denyut jantung $\geq 120$ kali per menit), denyut jantung janin $>160$ kali per menit, uterus teraba lunak, jumlah sel leukosit $>11,000$ $\mathrm{sel} / \mathrm{mm}^{3}$ dan ketuban pecah lebih dari 18 jam sebelum persalinan. Bayi dimasukkan dalam kelompok kasus apabila memenuhi kriteria inklusi, eksklusi, dan air ketuban keruh dengan pemeriksaan sterkobilin positif, sedangkan kelompok kontrol apabila memenuhi kriteria inklusi, eksklusi, serta air ketuban tidak keruh dengan pemeriksaan sterkobilin negatif. Pengambilan sampel dilakukan dengan consecutive sampling. 
Besar sampel dihitung dengan rumus besar sampel penelitian kohort, tingkat kemaknaan a 5\% dan power $80 \%$. Nilai risiko relatif (RR) kejadian sepsis pada neonatus ditentukan berdasar penelitian oleh Dexter dkk mengenai kejadian sepsis pada bayi dengan ibu korioamnionitis yang dipublikasikan dalam Obstetri Gynecologi tahun 2000, yaitu sebesar 5,1. Setelah diperhitungkan dengan koreksi drop out besar sampel minimal 34 bayi per kelompok.

Tahapan penelitian dimulai dari ibu bayi baru lahir yang telah memberikan inform consent diambil air ketubannya, dengan sebelumnya didesinfeksi dengan menggunakan alkohol. Air ketuban diambil oleh dokter obstetri dengan menggunakan spuit disposiable sebanyak $10 \mathrm{cc}$ pada persalinan letak kepala dan dilakukan pengambilan sesaat setelah rahim dibuka pada persalinan dengan sectio cesarea. Air ketuban dilakukan pemeriksaan makroskopis, kimia, pengecatan Gram, dan kultur dengan menjaga sterilitas air ketuban. Bayi yang dilahirkan dari ibu dengan air ketuban keruh akan dirawat sesuai dengan kondisi saat itu (PBRT, NICU maupun di rawat gabung) dan dilakukan pengamatan dan sampai ditentukan secara klinis terjadi sepsis neonatus awitan dini dan dilakukan pemeriksaan darah rutin, gambaran darah tepi, pengecatan Gram dan biakan darah bayi yaitu sekitar hari kelima. Diagnosis sepsis bayi ditentukan dengan pemeriksaan klinis, darah rutin, dan biakan darah.
Variabel dinyatakan sebagai faktor risiko apabila nilai $\mathrm{OR}>1$, dan dinyatakan sebagai faktor protektif apabila $\mathrm{OR}<1$. Penilaian faktor risiko juga berdasarkan rentang interval kepercayaan 95\% (95\% confidence interval $=\mathrm{CI}$ ). Apabila rentang nilai 95\% CI melingkupi angka 1 maka variabel tersebut belum dapat disimpulkan sebagai faktor risiko (inconclusive). Nilai $\mathrm{p}$ dianggap bermakna apabila $\mathrm{p}<0,05$ dengan $95 \%$ interval kepercayaan. Analisis statistik menggunakan program SPSS for Windows versi 15.

Penelitian telah mendapat persetujuan Komite Etik Penelitian Kesehatan Fakultas Kedokteran Universitas Diponegoro/RSUP Dr. Kariadi Semarang.

\section{Hasil}

Penelitian melibatkan 70 bayi baru lahir yang terdiri atas 35 bayi lahir dari ibu dengan air ketuban keruh dan 35 bayi lahir dari ibu dengan air ketubah tidak keruh. Seluruh bayi yang menjadi subyek penelitian berumur satu hari. Karakteristik bayi berdasarkan adanya kekeruhan air ketuban tertera pada Tabel 1 .

Tabel 1 menunjukkan sebaran jenis kelamin antara kelompok air ketuban keruh adalah sama dengan air ketuban tidak keruh. Masa gestasi pada kedua kelompok sebagian besar adalah 37-41 minggu, masa gestasi $>41$ minggu hanya dijumpai 2 kasus pada tiap kelompok

Tabel 1. Karakteristik subyek penelitian

\begin{tabular}{|c|c|c|c|}
\hline \multirow{2}{*}{ Karakteristik } & \multicolumn{2}{|c|}{ Status air ketuban } & \multirow{2}{*}{$\mathrm{p}$} \\
\hline & Keruh & Tidak keruh & \\
\hline \multicolumn{4}{|l|}{ Jenis kelamin (n, \%) } \\
\hline - Laki-laki & $19(27,1)$ & $19(27,1)$ & \\
\hline - Perempuan & $16(22,9)$ & $16(22,9)$ & $1,0^{*}$ \\
\hline \multicolumn{4}{|l|}{ Masa gestasi (minggu, \%) } \\
\hline$->41$ & $2(2,9)$ & $2(2,9)$ & \\
\hline$-37-41$ & $33(47,1)$ & $33(47,1)$ & $1,0^{9}$ \\
\hline Berat badan lahir (gram) & $3000(2200-4100)$ & $3200(2500-4300)$ & $0,03^{\S}$ \\
\hline Panjang badan lahir $(\mathrm{cm})$ & $48(42-51)$ & $49(45-53)$ & $0,2^{\S}$ \\
\hline \multicolumn{4}{|l|}{ Cara lahir (n, \%) } \\
\hline - Spontan & $10(14,3)$ & $6(8,6)$ & \\
\hline - Ekstraksi vakum & $10(14,3)$ & $2(2,9)$ & \\
\hline - Sectio cesarea & $15(21,4)$ & $27(38,6)$ & $0,008^{*}$ \\
\hline \multicolumn{4}{|l|}{ Penolong persalinan (n, \%) } \\
\hline - Dokter & $35(50,0)$ & $35(50,0)$ & \\
\hline - Bidan & $0(0,0)$ & $0(0,0)$ & - \\
\hline
\end{tabular}

${ }^{*}$ Uji $\chi^{2},{ }^{9}$ Uji Fisher Exact, ${ }^{5}$ Uji Mann-Whitney 
air ketuban keruh maupun tidak keruh, secara statistik perbedaan tersebut adalah tidak bermakna $(\mathrm{p}=1,0)$. Berdasarkan berat lahir tampak berat lahir kelompok air ketuban keruh lebih rendah secara bermakna dibanding air ketuban tidak keruh $(\mathrm{p}=0,03)$. Panjang badan kelompok ketuban tidak keruh adalah lebih panjang dibanding air ketuban keruh, akan tetapi perbedaan tersebut adalah tidak bermakna $(\mathrm{p}=0,2)$. Cara lahir terbanyak pada kedua kelompok adalah dengan sectio cesaria, lahir secara spontan lebih banyak pada kelompok air ketuban keruh. Hasil uji statistik menunjukkan perbedaan tersebut bermakna $(\mathrm{p}=0,008)$. Penolong persalinan seluruhnya dilakukan oleh dokter.

Tabel 2 menunjukkan kejadian sepsis lebih banyak dijumpai pada bayi yang lahir dengan air ketuban keruh. Penghitungan besarnya risiko relatif (RR) menunjukkan bahwa bayi yang lahir dengan air ketuban keruh mempunyai risiko untuk menderita sepsis 10,0 kali lebih besar dibanding yang lahir dengan air ketuban tidak keruh (CI 1,3-74,0, $\mathrm{p}=0,003)$.
Tabel 3 menunjukkan berdasarkan hasil pengecatan Gram penyebab sepsis yang terbanyak dijumpai adalah kedua jenis bakteri Gram (-) dan (+), selanjutnya adalah kuman Gram (+), sedangkan bakteri Gram (-) tidak dijumpai sebagai penyebab sepsis awitan dini. Namun hasil uji statistik menunjukkan perbedaan distribusi bakteri tidak bermakna $(\mathrm{p}=0,3)$. Nilai $\mathrm{RR}$ pengecatan kuman Gram (+) pada air ketuban terhadap kejadian sepsis 1,4 (95\% CI=0,3-6,8; $\mathrm{p}=0,6)$. Nilai RR adanya kedua jenis kuman Gram (-) dan (+) pada air ketuban 2,4 (95\% CI=0,7-7,7; $\mathrm{p}=0,2)$. Hal ini berarti bahwa hasil pengecatan Gram (+), Gram $(-)$, dan (+) hasil bukan merupakan faktor risiko sepsis awitan dini bayi baru lahir.

Tabel 4 menunjukkan hasil perhitungan risiko relatif adanya kuman $E$ coli pada biakan air ketuban untuk kejadian sepsis awitan dini 3,8 (95\% CI=0,817,0; $\mathrm{p}=0,057)$, sedangkan nilai $\mathrm{RR}$ untuk jenis bakteri non $E$ coli adalah $2,4(95 \% \mathrm{CI}=0,4-13,1 ; \mathrm{p}=0,4)$. Hal tersebut berarti $E$ coli dan non $E$ coli bukan merupakan

Tabel 2. Kejadian sepsis awitan dini berdasarkan kekeruhan air ketuban

\begin{tabular}{|c|c|c|c|c|}
\hline \multirow[b]{2}{*}{ Air ketuban } & \multicolumn{2}{|c|}{ Sepsis awitan dini } & \multirow[b]{2}{*}{$\mathrm{p}$} & \multirow[b]{2}{*}{ RR (95\% CI) } \\
\hline & $\begin{array}{l}\text { Sepsis } \\
(\mathrm{n}=11)\end{array}$ & $\begin{array}{c}\text { Tidak } \\
(\mathrm{n}=59) \\
\end{array}$ & & \\
\hline Keruh & $10(14,3 \%)$ & $25(35,7 \%)$ & & \\
\hline Tidak keruh & $1(1,4 \%)$ & $34(48,6 \%)$ & 0,003 & $10,0(1,3-74,0)$ \\
\hline \multicolumn{5}{|l|}{$\mathrm{Uji} \chi^{2}$} \\
\hline \multicolumn{5}{|c|}{ Tabel 3. Kejadian sepsis awitan dini berdasarkan jenis bakteri air ketuban } \\
\hline \multirow[b]{2}{*}{ Jenis bakteri air ketuban } & \multicolumn{3}{|c|}{ Sepsis awitan dini $(\mathrm{n}, \%)$} & \multirow[b]{2}{*}{ RR (95\% CI) } \\
\hline & & $\begin{array}{l}\text { Sepsis } \\
(\mathrm{n}=11)\end{array}$ & $\begin{array}{c}\text { Tidak sepsis } \\
(\mathrm{n}=59)\end{array}$ & \\
\hline Tidak didapatkan bakteri & & $4(5,7)$ & $30(42,9)$ & \\
\hline Bakteri Gram (-) & & $0(0,0)$ & $6(8,6)$ & \\
\hline Bakteri Gram (+) & & $2(2,9)$ & $10(14,3)$ & $1,4(0,3-6,8)$ \\
\hline Bakteri Gram (-) dan $(+)$ & & $5(7,1)$ & $13(18,6)$ & $2,4(0,7-7,7)$ \\
\hline
\end{tabular}

$\mathrm{p}=0,3$, Uji Fisher-exact (tabel r by c: 3X2)

Tabel 4. Kejadian sepsis awitan dini berdasarkan kategori biakan air ketuban

\begin{tabular}{llcc}
\hline \multirow{2}{*}{ Jenis biakan air ketuban } & \multicolumn{2}{c}{ Sepsis awitan dini $(\mathrm{n}, \%)$} & \multirow{2}{*}{ RR $(95 \% \mathrm{CI})^{\S}$} \\
\cline { 2 - 3 } & $\begin{array}{l}\text { Sepsis } \\
(\mathrm{n}=11)\end{array}$ & $\begin{array}{c}\text { Tidak sepsis } \\
(\mathrm{n}=5 \%)\end{array}$ & \\
\hline Tidak ada pertumbuhan bakteri & $2(2,9)$ & $27(38,6)$ & 1,0 \\
$E$ coli & $6(8,6)$ & $17(24,3)$ & $3,8(0,8-17,0)$ \\
Non $E$ coli & $3(4,3)$ & $15(21,4)$ & $2,4(0,4-13,1)$ \\
\hline $\mathrm{p}=0,2$ & & & \\
Uji $\chi^{2}$ (tabel $\mathrm{r}$ by c: 3X2) & & \\
${ }^{\circledR}$ Dihitung pada tabel 2X2 dengan kelompok tidak ada pertumbuhan kuman sebagai rujukan & &
\end{tabular}


faktor risiko kejadian sepsis awitan dini.

Tabel 5 menunjukkan besarnya risiko relatif (RR) faktor bayi tidak bugar untuk mengalami sepsis pada penelitian ini tidak dapat dihitung oleh karena adanya sel yang kosong pada sel tabel $2 \times 2$. Besarnya RR untuk faktor gravida $>2$ untuk sepsis awitan dini adalah 0,2 (95\% CI =0,03-1,6; p=0,08). Besarnya nilai RR untuk cara lahir dengan tindakan untuk kejadian sepsis awitan dini 1,3 (95\% CI=0,3-5,5; p=0,7). Nilai RR adanya bakteri pada air ketuban untuk terjadinya sepsis awitan dini adalah $2(95 \% \mathrm{CI}=0,6-6,9 ; \mathrm{p}=0,3)$. Faktor ini belum dapat disimpulkan sebagai faktor risiko menimbang rentang $95 \%$ CI yang masih melingkupi angka 1. Nilai RR adanya kuman dalam darah untuk terjadinya sepsis awitan dini adalah 5,5 (95\% CI=1,6$18,6 ; \mathrm{p}=0,002)$. Hal ini berarti bayi terdapat kuman dalam biakan darah mempunyai risiko untuk menderita sepsis awitan dini 5,5 kali lebih besar dibanding yang tidak terdapat kuman dalam biakan darah, sedangkan faktor jumlah gravida, cara lahir dan hasil biakan ketuban belum dapat disimpulkan sebagai faktor risiko sepsis awitan dini bayi baru lahir.

\section{Pembahasan}

Bayi lahir dengan air ketuban keruh mempunyai risiko untuk menderita sepsis 10 kali lebih besar dibanding lahir dengan air ketuban tidak keruh. Air ketuban merupakan media kultur yang kurang baik untuk bakteri, tetapi jika ada sejumlah mekonium yang ada di dalamnya dapat meningkatkan pertumbuhan bakteri terutama Escherichia coli dan Listeria monocytogenes. Janin yang terpapar air ketuban bercampur mekonium memiliki risiko lebih tinggi terhadap infeksi daripada bayi dengan air ketuban tidak keruh. ${ }^{14}$ Rao $S^{12}$ menyebutkan bahwa pada plasenta dengan gambaran chorioamnionitis akut berbeda secara bermakna pada kejadian bayi presumed sepsis dibanding plasenta dengan gambaran histologis normal. Gambaran plasenta chorioamnionitis akut memiliki insiden air ketuban keruh bercampur mekonium lebih banyak dibanding plasenta tanpa gambaran histologis chorioamnionitis akut. Hal ini serupa dengan penelitian Shah $\mathrm{dkk}^{15}$ yang menyebutkan bahwa terdapat perbedaan secara bermakna air ketuban keruh bercampur mekonium dengan air ketuban tidak keruh terhadap terjadinya sepsis dengan $\mathrm{p}=0,040$ dan $\mathrm{OR}=2,19$.

Hasil uji statistik menunjukkan bahwa pada air ketuban dengan kuman Gram (+) mempunyai risiko untuk kejadian sepsis awitan dini 1,4 kali lebih besar dibanding bayi dengan air ketuban steril. Adanya kedua jenis kuman Gram (-) dan (+) pada air ketuban mempunyai risiko kejadian sepsis awitan dini 2,4 kali lebih besar dibanding bayi dengan air ketuban steril; tetapi rentang nilai 95\% CI untuk faktor adanya

Tabel 5. Faktor-faktor yang berpengaruh pada kejadian sepsis awitan dini neonatus

\begin{tabular}{|c|c|c|c|c|}
\hline \multirow{2}{*}{$\begin{array}{l}\text { Faktor yang mempengaruhi kejadian } \\
\text { sepsis }\end{array}$} & \multicolumn{2}{|c|}{ Sepsis $(\mathrm{n}, \%)$} & \multirow{2}{*}{$\mathrm{p}$} & \multirow{2}{*}{$\mathrm{RR}$} \\
\hline & Ada & Tidak & & \\
\hline \multicolumn{5}{|l|}{ Kebugaran bayi } \\
\hline Tidak bugar & $11(15,7)$ & $3(4,3)$ & & \\
\hline Bugar & $0(0,0)$ & $56(80,0)$ & $<0,001$ & - \\
\hline \multicolumn{5}{|l|}{ Kategori gravida } \\
\hline$>2$ & $1(1,4)$ & $21(30,0)$ & & \\
\hline $1-2$ & $10(14,3)$ & $38(54,3)$ & 0,08 & $0,2(0,03-1,6)$ \\
\hline \multicolumn{5}{|l|}{ Cara lahir } \\
\hline Tindakan & $9(12,9)$ & $45(64,3)$ & & \\
\hline Spontan & $2(2,9)$ & $14(20,0)$ & 0,7 & $1,3(0,3-5,5)$ \\
\hline \multicolumn{5}{|l|}{ Biakan ketuban } \\
\hline Positif & $8(11,4)$ & $32(45,7)$ & & \\
\hline Tidak ada pertumbuhan kuman & $3(4,3)$ & $27(38,6)$ & 0,3 & $2(0,6-6,9)$ \\
\hline \multicolumn{5}{|l|}{ Biakan darah } \\
\hline Positif & $8(11,4)$ & $15(21,4)$ & & \\
\hline Tidak ada pertumbuhan kuman & $3(4,3)$ & $44(62,9)$ & 0,002 & $5,5(1,6-18,6)$ \\
\hline
\end{tabular}

Sari Pediatri, Vol. 12, No. 3, Oktober 2010 
kuman Gram (+) dan kedua jenis kuman Gram (-) dan (+) pada air ketuban yang masih melingkupi angka 1, maka kedua faktor tersebut belum dapat disimpulkan sebagai faktor risiko kejadian sepsis awitan dini pada bayi baru lahir.

Kejadian sepsis awitan dini berdasarkan kategori biakan kuman pada air ketuban yang dikategorikan menjadi kelompok E. coli dan non E. coli, pemilihan kategori tersebut karena $E$ coli sebagai kuman terbanyak yang ditemukan pada biakan kuman. Hasil uji statistik menunjukkan bahwa RR adanya kuman $E$ coli dan non $E$ coli belum dapat disimpulkan sebagai faktor risiko kejadian sepsis awitan dini bayi baru lahir, sehingga hipotesis minor tidak terbukti. Air ketuban keruh pada penelitian ini merupakan faktor risiko terjadinya sepsis awitan dini, tetapi adanya biakan kuman pada air ketuban keruh tidak terbukti secara bermakna merupakan faktor risiko terhadap kejadian sepsis awitan dini pada bayi baru lahir; sehingga pengamatan klinis dan pemeriksaan biakan darah pada bayi dengan kecurigaan sepsis tetap mutlak dilakukan.

Faktor kebugaran bayi secara bermakna mempengaruhi bayi sepsis. Hal ini sesuai dengan penelitian Shah yang menyebutkan bahwa terdapat perbedaan bermakna antara Apgar score 1 menit $<7$ dengan $\geq 7, p=0,0001$ dan OR 5,70. ${ }^{15}$ Kategori gravida $>2$ lebih banyak dijumpai pada kelompok bayi tidak sepsis, akan tetapi pada hasil uji statistik menunjukkan perbedaan yang tidak bermakna $(p=0,08)$. Faktor jumlah gravida, cara lahir dan adanya biakan kuman tidak berpengaruh terhadap kejadian sepsis awitan dini.

Bayi yang lahir tidak bugar sering disertai dengan kejadian asfiksia. Asfiksia pada bayi baru lahir merupakan faktor yang mempermudah terjadinya infeksi sistemik. Hal ini disebabkan aktivitas leukosit terhambat karena membutuhkan ATP untuk kontraksi sitoskeletal mikrofilamen. Keadaan hipoksia juga akan menghambat aktivitas mikrobisidal PMN. ${ }^{16}$

Hasil biakan darah bayi sepsis sebagian besar menunjukkan adanya biakan dalam darah, sebaliknya pada bayi tidak sepsis sebagian besar hasil biakan tidak terdapat adanya bakteri dalam darah. Hasil uji statistik menunjukkan perbedaan tersebut adalah bermakna $(\mathrm{p}=0,002)$. Nilai risiko relatif $(\mathrm{RR})$ biakan darah terhadap kejadian sepsis 5,5, dengan confidence interval CI 1,6-18,6. Hal ini berarti bahwa bayi dengan adanya kuman dalam darah mempunyai risiko menderita sepsis awitan dini 5,5 kali lebih besar dibanding yang tidak ada biakan dalam darah.

Adapun hal-hal yang merupakan keterbatasan penelitian adalah kesulitan teknik pengambilan air ketuban pada ibu yang melahirkan per vaginam dalam menjaga sterilitasnya, meskipun telah dilakukan secara aseptis. Terdapat perbedaan hasil pengecatan air ketuban dengan hasil biakan, hal ini mungkin disebabkan karena teknik pengambilan sampel untuk pengecatan tidak homogen dan pemeriksaan ini sangat dipengaruhi oleh subyektivitas pemeriksa.

\section{Kesimpulan}

Air ketuban keruh merupakan faktor risiko terhadap kejadian sepsis awitan dini bayi baru lahir. Selain air ketuban keruh, keadaan bayi tidak bugar dan biakan kuman dalam darah juga merupakan faktor risiko terjadinya sepsis awitan dini. Jenis diplococcus yang didapatkan dengan pengecatan Gram pada air ketuban keruh merupakan kuman terbanyak pada air ketuban keruh yang menimbulkan sepsis. Jenis kuman E. coli disusul S. epidermidis dan $S$. aureus yang didapatkan dari biakan air ketuban keruh merupakan bakteri terbanyak yang menimbulkan sepsis pada air ketuban keruh, namun kedua jenis bakteri ini belum dapat disimpulkan sebagai faktor risiko kejadian sepsis awitan dini pada bayi baru lahir.

Mengingat kondisi tidak bugar merupakan faktor risiko terjadinya sepsis awitan dini pada bayi baru lahir dengan air ketuban keruh, maka harus diupayakan untuk melakukan resusitasi dengan cepat baik dan benar. Pengamatan klinis dan pemeriksaan biakan darah pada bayi lahir dengan air ketuban keruh dan kecurigaan sepsis tetap mutlak dilakukan. Bila fasilitas dan sumber daya lain memungkinkan permeriksaan polimerase chain reaction (PCR) dapat dilakukan sebagai alternatif untuk menentukan adanya pemeriksaan kuman dengan hasil pengecatan terdapat kuman tetapi hasil biakan tidak terdapat kuman.

\section{Daftar pustaka}

1. Aminullah A. Masalah terkini sepsis neonatorum. Dalam: Hegar B, Trihono PP, Irfan EB penyunting. Update in neonatal infection. Naskah lengkap pendidikan kedokteran berkelanjutan IKA XLVIII. 
Jakarta: Balai Penerbit FKUI; 2005. h.1-13.

2. Child health research. Project special report : reducing perinatal and neonatal mortality, report of a meeting, Baltimore, Maryland,1999;3:6-12. Didapat dari : http:// www.reproline.jhu.edulenglish/2mnh/perinatal.pdf

3. Lawn J. The healthy newborn: A reference manual for program managers.Available at: www.cdc.gov/nccdphp/drh/ health_newborn.htm.

4. Gerdes JS. Diagnosis and management of bacterial infection in the neonate. Pediat Clin N Am 2004; 51: 939-59

5. Rohsiswatmo R. Kontroversi diagnosis sepsis neonatorum. Dalam: Hegar B, Trihono PP, Irfan EB penyunting. Update in neonatal infection. Naskah lewngkap pendidikan kedokteran berkelanjutan IKA XLVIII. Jakarta: Balai Penerbit FKUI; 2005.h.32-4.

6. Anonymous. Protap pelayanan perinatal risiko tinggi RSDK. Unpublished.

7. Gomella TL. Neonatal sepsis. Dalam: Gomella TL, Cunningham MD, Eyal FG, Zenk KE penyunting. Neonatology Management Procedures on Call Problem Diseases Drugs. Edisi ke-4. New York: Lange Medical Books/McGraw Hill;1999.h.408-14

8. Bellig LL, Ohning BL. Neonatal sepsis. Didapat dari: http:/lauthor.emedicine.com/PED/topic2630.htm.

9. Jazayeri A, Jazayeri MK, Sahinler M, Sincich T. Is meconium passage a risk factor for maternal infection in term pregnancies? Obstet Gynecol 2002; 99:548-52.
10. Adair CD, Ernest JM, Ramos LS, Burrus DR, Boles ML, Veille JC. Meconium stained amniotic fluid associated infectious morbidity : a randomized, double-blind trial of ampicillin-sulbactam prophylaxis. Obstet Gynecol 1996; 88:216-20.

11. Tran SH, Caughney AB, Musci TJ. Meconium stained amniotic fluid is associated with puerperal infections. Obstet Gynecol 2002;189:746-50.

12. Rao S. Pavlova Z, Incerpi MH, Ramanathan R. Meconium stained amniotic fluid and neonatal morbidity in near term and term deliveries with acute histologic chorioamnionitis and/or funisitis. J Perinatol 2001;21:537-40.

13. Chiesa C, Alessandra Panero A, Osborn JF, Simonetti AF, Pacifico1 L. Diagnosis of neonatal sepsis: a clinical and laboratory challenge. Clinical Chemistry 2004;50:279-87

14. Romero R, Hanoaka S, Mazor M, Athanassiadis AP, Callahan R, Hsu YC, Nores J, Jimenez C. Meconium stained amniotic fluid: a risk factor for microbial invasion of the amniotic cavity. Am J Obstet Gynecol 1991;164:859-62.

15. Shah GS, Budhathoki S, Das BK Mandal RN. Risk factor in early neonatal sepsis. Kathmandu University Medical Journal 2006;4:187-91.

16. Yoder MC, Pollin RA. Developmental immunology. Dalam: Klaus MH, Fanaroff AA penyunting. Care of the high risk neonate. Edisi ke-5. Philadelphia: W.B. Saunders Company; 2001. h. 78-85. 